\title{
Somatic, Biochemical and Hepatic Alterations in Wild Type Mice Chronically Fed High Fat Diet
}

\author{
Alteraciones Somáticas Bioquímicas y hepáticas en un Tipo de Ratas Alimentadas Crónicamente \\ con Dieta Alta en Grasas

\begin{abstract}
*;*** Renata Heisler Neves; "Alba Cristina Miranda de Barros Alencar; **Marcia Barbosa Aguila; ** Carlos Alberto Mandarimde-Lacerda; * José Roberto Machado-Silva \& *** Delir Corrêa Gomes.
\end{abstract}

NEVES, R. H.; ALENCAR, A. C. M. B.; AGUILA, M. B.; MANDARIM-DE-LACERDA, C.A.; MACHADO-SILVA, J. R. \& GOMES, D. C. Somatic, biochemical and hepatic alterations in wild type mice chronically fed high fat diet. Int. J. Morphol., 24(4):625-632, 2006.

SUMMARY: This study evaluated whether a high fat diet (HFC group) induces overweight, hepatic steatosis and plasma lipoproteins level alteration compared to standard chow diet (SC group). Female mice were submitted to each diet over 6 months. Body mass and food intake were evaluated weekly throughout the experiment. Total cholesterol, TG, LDL-c, HDL-c and VLDL-c were analyzed. Mice were sacrificed to remove liver, spleen, heart and intestine. The volume of the organs was determined according to the submersion method. Fixed livers were embedded in paraffin and stained with hematoxylin and eosin and Masson's trichrome. The analysis used a video microscope system and a test-system with 42 test-points. The volume density was estimated for hepatocytes, steatosis and sinusoids. Animals fed HFC had smaller chow intake than SC group. HFC group presented body mass greater than SC. Animals fed HFC showed heavier liver and spleen and lighter intestine than SC $(\mathrm{p}<0.05)$, heart mass was not significant between groups. Plasma lipoproteins differed between groups $(\mathrm{p}<0.05)$ except VLDL-c and TG fractions. The liver structure was without major alteration in SC group however, HFC mice group showed different degrees of fatty degeneration with micro- and macrovesicular steatosis dispersed in all liver with typical peri-cellular/peri-sinusoidal fibrosis. The quantitative study showed significant $(\mathrm{p}<0.05)$ volume density reduction for hepatocytes and sinusoids. In conclusion, our results clearly show that hepatic steatosis can be induced in mouse by such a fat-rich diet without any toxin ingestion, alimentary deficiency and genes depletion.

KEY WORDS: Hypercholesterolemia; Experimental model; Mice; Cholesterol; Diet; Liver.

\section{INTRODUCTION}

The increased intake of dietary fat is one of the most important environmental factors explaining the increased prevalence of obesity in western societies (Schrauwen \& Westerterp, 2000) and diseases associated with obesity, i.e. inflammatory and chronic diseases like hypertension (Aguila et al., 2004; Alexaki et al., 2004; Mohr et al., 2004) as well as in the host immune response (Feingold et al., 2004). Obesity is also the most significant single risk factor for the development of fatty liver (Hu et al., 2004). Fatty liver, or steatosis, refers to a histopathological condition characterized by an excess accumulation of lipids, primarily tricylglycerols (TG), within hepatocytes (Burt et al., 1998). The clinical significance of fatty liver is generally thought to be a benign process. However, simple steatosis may progress to advanced fibrosis and to cryptogenic cirrhosis through steatohepatitis, and ultimately to hepatocellular carcinoma; obesity is also predictive of the presence of fibrosis, potentially progressing to advanced liver disease (Festi et al., 2004). Fatty liver can be classified as macrovesicular or microvesicular steatosis, depending on the size of the lipid vacuoles (Van Steenbergen \& Lanckmans, 1995; Marceau et al., 1999). In most instances, macrovesicular steatosis is at least potentially reversible and microvesicular steatosis is generally a more severe disease than the macrovesicular form and is seen in a variety of conditions in which there is either an inherited or an acquired defect in beta-oxidation of fatty acids; the former includes mitochondrial cytopathies and disorders of ureagenesis, and the latter includes acute fatty liver of pregnancy and Reye's syndrome (Burt et al.).

Increasing interest in the causes and the consequences of liver lipid infiltration has been the finding that an

\footnotetext{
* Laboratory of Helminthology Romero Lascasas Porto, Department of Microbiology, Immunology and Parasitology, Faculty of Medical Sciences, Brazil. ** Laboratory of Morphometry and Cardiovascular Morphology, Institute of Biology, Biomedical Centre, State University of Rio de Janeiro, Brazil.

**** Laboratory of Helminthes Parasites of Vertebrates, Department of Helminthology, Oswaldo Cruz Institute, Rio de Janeiro, Brazil.
} 
association exists between the accumulation of TG in tissues other than adipocytes and the development of a state of insulin resistance (Saltiel \& Kahn, 2001). Studies in fatless mice have demonstrated that fat accumulation in skeletal muscle and liver is associated with insulin resistance and insulin signaling defects (Kim et al., 2000; Reue et al., 2000). The use of experimental models derived from common small laboratory animals has provided new insights into the knowledge of lipoprotein metabolism. There are direct association between fat consumption and hepatic steatosis in rats, long-term administration of lard and egg yolk attenuates hepatic fat accumulation and increases hepatic sinusoids. The administration of the canola oil and lard and egg yolk mixture increases hepatic fat accumulation, reducing the hepatic sinusoids (Aguila et al., 2003).

The study of rodent behavior in adverse nutritional environment is important because these animals are largely used in experimental studies including diet manipulation. Present work was aimed at evaluating whether a high fat diet-induced overweight/obesity in wild type mice could develop hepatic steatosis, plasma lipoproteins level alteration and differential increase in body and organs weights compared to normal chow fed mice.

\section{MATERIAL AND METHOD}

Mice. Female Swiss Webster mice (3 wk old) were obtained from the Laboratory Animals Breeding Center (Oswaldo Cruz Foundation, Brazil) and appropriated housed. Mice were kept in a temperature $\left(21 \pm 1^{\circ} \mathrm{C}\right)$ and humidity-controlled $(60 \pm 10 \%)$ room, exposed to a $12 \mathrm{~h}$ light and dark cycle (artificial lights) and to an air exhaustion cycle. All animal procedures were in accordance with the ethical procedures with investigated animals and were approved by the Oswaldo Cruz Foundation Animal Ethics Committee (PO105-02).

Diets. In experimental group mice fed a high-fat chow (HFC, $\mathrm{n}=20$ ) containing lard, egg yolks, wheat flour, corn starch, casein and vitamins and minerals mixture $(47 \%$ carbohydrates, $24 \%$ proteins, $29 \%$ lipids $)(5.7 \mathrm{kcal} / \mathrm{g}$ body wt./day) (Aguila et al., 2002) for a period of 30 weeks. The ingredients were purchased from commercial sources and were weekly prepared in our laboratory and stored at $+4{ }^{\circ} \mathrm{C}$. The major ingredient proportions and the total combustible energy $(\mathrm{kj} / \mathrm{kg}$ and $\mathrm{kcal} / \mathrm{kg})$ of HFC are shown in Table I (Lentner, 1981). Standard mice chow group (SC, $n=20)$ fed a commercial standard chow (Nuvilab, Parana, Brazil) containing $12 \%$ fat, $28 \%$ protein, and $60 \%$ carbohydrate $(4.6$ $\mathrm{kcal} / \mathrm{g}$ body wt/day). All animals were allowed to have free access to water and food during the study.

\begin{tabular}{lr}
\hline Component & $\begin{array}{r}\text { Quantity } \\
(\mathrm{g} / \mathrm{kg})\end{array}$ \\
\hline Casein & 305.0 \\
Corn starch & 150.0 \\
Wheat flour & 245.0 \\
Egg yolk & 180.0 \\
Lard & 120.0 \\
Total & $1,000.0$ \\
Vitamin mixture (mg)* & 50.0 \\
Mineral mixture (mg)** & 30.0 \\
Cholesterol & 3.0 \\
Kcal/Kg & $5,734.0$ \\
Kj/Kg & $23,968.0$ \\
\hline
\end{tabular}

Table I. Composition of the experimental high fat chow $(\mathrm{g} / \mathrm{kg})$. *Vitamin mixture: $50.0 \mathrm{mg}$. Vitamins (per $\mathrm{Kg}$ of diet): thiamine, $6.5 \mathrm{mg}$; riboflavin, $5.3 \mathrm{mg}$; pyridoxine, $6.3 \mathrm{mg}$; niacin, $7.5 \mathrm{mg}$; folic acid, $1.3 \mathrm{mg}$; biotin, $0.5 \mathrm{mg}$; cyanocobalamin, $0.19 \mathrm{mg}$; retinyl palmitate, $1562 \mathrm{UI}$; cholecalciferol, $1250 \mathrm{UI}$; tocopheryl acetate, $81.3 \mathrm{mg}$; ascorbic acid, $185 \mathrm{mg}$. ** Mineral mixture: $30.0 \mathrm{mg}$. Minerals (mg per Kg of diet): calcium, 6000; phosphorus, 5000; sodium, 500; potassium, 1800; chlorine, 500; magnesium, 400; manganese, 50; iron, 35; zinc, 29; copper, 5; fibers, 11.5g.

Biometry, sample and procedures. Body mass and food intake were evaluated twice a week throughout the experiment. Blood samples were obtained by puncture of the retro orbital sinus. Plasma was collected from fooddeprived mice (overnight) for plasma lipid measurements. Plasma samples were obtained after blood was centrifuged at $120 \mathrm{~g}$ for $15 \mathrm{~min}$ and stored at $-80^{\circ} \mathrm{C}$ until the lipids were analyzed. All the lipids were extracted by the colorimetric enzymatic method. Total cholesterol (TC) was determined by cholesterol esterase/ cholesterol oxidase/peroxidase method, triglycerides (TG) were measured using glycerol phosphate oxidase/peroxidase method. The low and very low density lipoproteins (LDL-c and VLDL-c) and chylomicron fractions were abundantly precipitated by the addition of phosphotungsten acid in the presence of magnesium ions. After centrifugation the cholesterol concentration in the high density lipoprotein (HDL-c) fraction, which remained in suspension, was determined. Fiedewald's formula (Friedewald et al., 1972) was used to determine the LDLcholesterol: LDL-c $=$ TC $-($ HDL-c - VLDL-c), where VLDL$\mathrm{c}=\mathrm{TG} / 5$.

Tissue processing and stereology. All mice were euthanized by cervical dislocation. A midline incision was made in the thorax and abdomen of the mice to remove liver, spleen, heart and small and large intestines (from the junction between stomach and duodenum until the middle part of the 
rectum into the pelvic cavity. The volume of the organs was determined according to the submersion method (Scherle, 1970) in which the water displacement due to organ volume is recorded by weighing $(\mathrm{W})$. As the isotonic saline specific density (d) is of 1.0048 the respective volumes were obtained by V[structure] $\left(\mathrm{cm}^{3}\right)=\mathrm{W}(\mathrm{g}) / \mathrm{d}$ or simply V $\left(\mathrm{cm}^{3}\right)=\mathrm{W}(\mathrm{g})$ (Weibel et al., 1966).

Livers were fixed by immersion with fixative (freshly prepared $4 \% \mathrm{w} / \mathrm{v}$ formaldehyde in $0.1 \mathrm{M}$ phosphate buffer $\mathrm{pH}$ 7.2) (Carson et al., 1973) and some random fragments were embedded in paraffin and sliced into $5 \mu \mathrm{m}$ sections. Sections were stained with hematoxylin and eosin (HE) and Masson's trichrome. Several slices were cut per fragment and five microscopic fields were randomly analyzed blindly in each animal moving freely the stage of the microscope. The analysis used a video microscope system (Olympus BX50 microscope, Sony RGB video-camera) and a testsystem with 42 test-points. The volume density was estimated for hepatocytes and its content in steatosis, and the sinusoids: $\left(\mathrm{Vv}[\right.$ structure $]:=\mathrm{Pp}[$ structure $\left.] / \mathrm{P}_{\mathrm{T}}\right)(\mathrm{Pp}$ is the number of points that hit the structure; $\mathrm{P}_{\mathrm{T}}$ is the total test-points) (Mandarimde-Lacerda, 2003).

Data analysis. The differences of the biometrical parameters between HFC and SC groups were tested by the Student- $t$ test. The stereological differences were tested using the nonparametric Mann-Whitney test (Glantz, 2002). All analyses were performed using GraphPad Prism version 4.03 for Windows (GraphPad Software, San Diego, CA, USA).

\section{RESULTS}

Animals showed varied average chow intake during the experiment. Animals fed $\mathrm{HFC}$ had smaller relative consumption than animals fed SC (all weeks $\mathrm{p}<0.05$, minimum difference was around $40 \%$ seen in week 23 , maximum difference was around $70 \%$ seen in week 18) (Fig. 1).

The body mass growth, after the first nine weeks for adaptation to the HFC, was greater in animals fed HFC than animals fed SC. The body mass comparing animals fed HFC with those fed SC was less $30 \%$ in week 2 and $0 \%$ in week 9 , but it was positive after the week 9 (maximum of $23 \%$ in week 15). Usually, differences equal or greater than $16 \%$ were significant between groups $(\mathrm{p}<0.05$; Fig. 2).

Animals fed HFC showed heavier liver and spleen and lighter intestine than animals fed SC, heart mass was not different between the groups (Fig. 3). Comparing animals fed SC with those fed HFC we observed that the liver mass varied from (mean $\pm \mathrm{SD}$ ) $2.48 \pm 0.24 \mathrm{~g}$ to $3.86 \pm 0.86 \mathrm{~g}$ and the spleen mass varied from $0.14 \pm 0.05 \mathrm{~g}$ to $0.28 \pm 0.11 \mathrm{~g}$. The intestine mass varied from $4.34 \pm 0.77 \mathrm{~g}$ to $2.28 \pm 0.50 \mathrm{~g}$ between the groups.

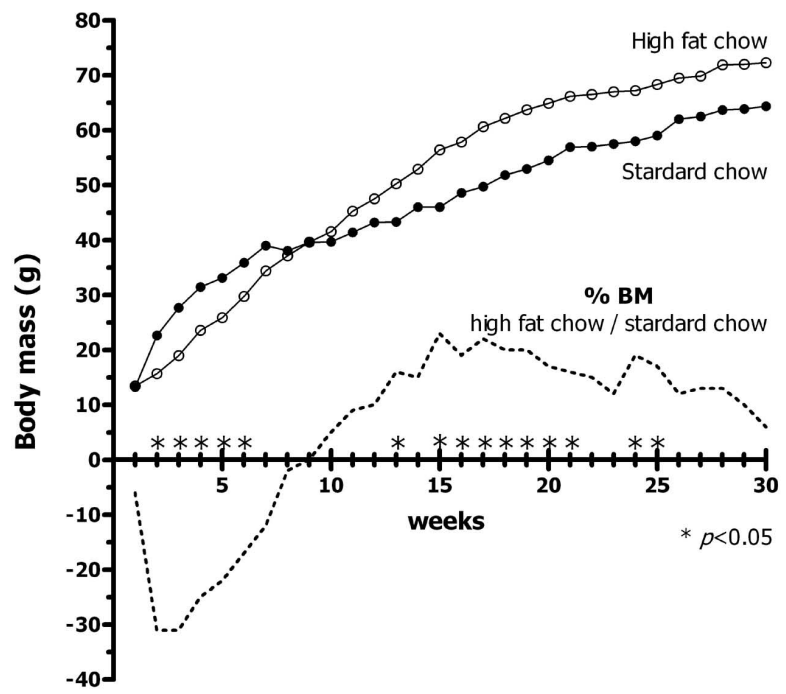

Fig. 1. Body mass variation during the experiment $(* \mathrm{p}<0.05$ between the groups in the marked week).

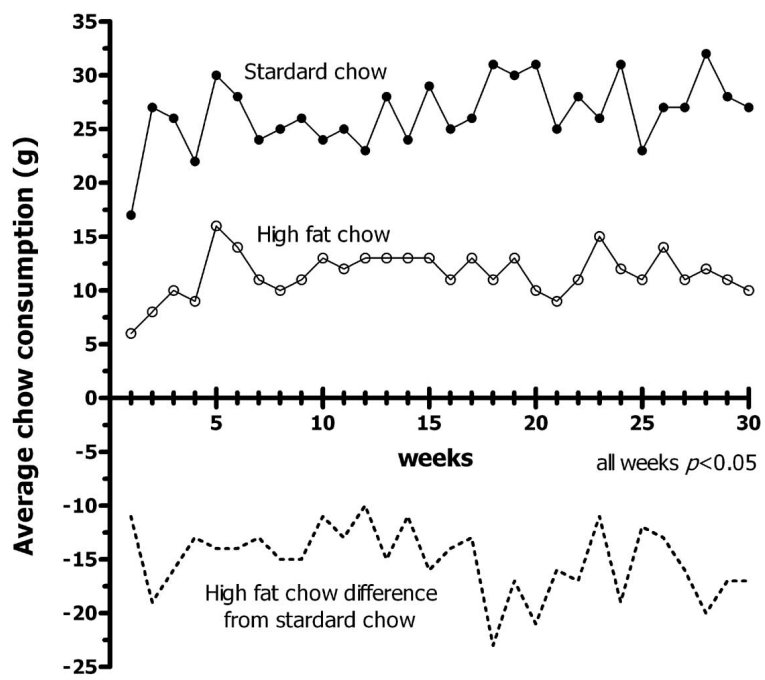

Fig. 2. Average chow consumption (g per animal). Differences were significant in all weeks $(\mathrm{p}<0.05)$.

Plasma lipoproteins were different between the two groups of animals except VLDL-c and TG that did not show difference between the groups. From normally fed animals to animals fed HFC the TC increased by $75 \%$ (from $3.00 \pm 0.88 \mathrm{mmol} / \mathrm{l}$ to $5.25 \pm 1.10 \mathrm{mmol} / \mathrm{l}, \mathrm{p}=0.0001$ ), HDL-c increased by $45 \%$ (from $1.23 \pm 0.49 \mathrm{mmol} / \mathrm{l}$ to $1.78 \pm 0.48$ $\mathrm{mmol} / \mathrm{l}, \mathrm{p}=0.001$ ) and LDL-c increased by $220 \%$ (from $0.66 \pm 0.31 \mathrm{mmol} / 1$ to $2.12 \pm 0.92 \mathrm{mmol} / \mathrm{l}, \mathrm{p}=0.0001$ ). 
NEVES, R. H.; ALENCAR, A. C. M. B.; AGUILA, M. B.; MANDARIM-DE-LACERDA, C. A.; MACHADO-SILVA, J. R. \& GOMES, D. C.

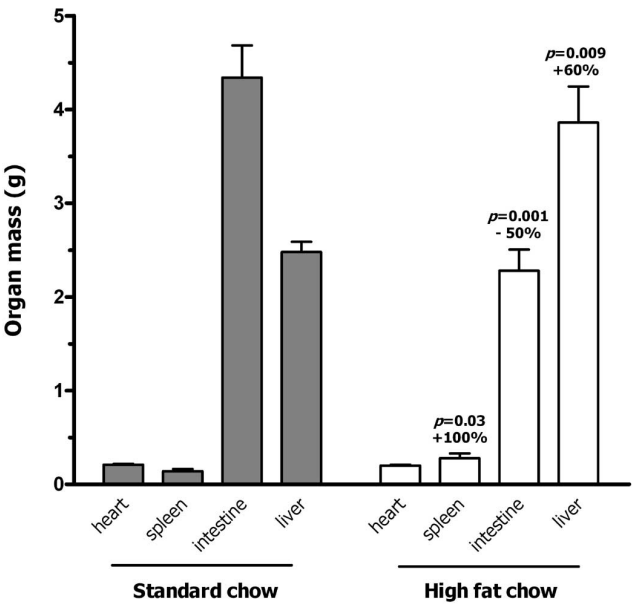

Fig. 3. Organ mass after 30 weeks of experiment. Significant differences between the groups, as well as the per cent variation, are indicated over the bars.
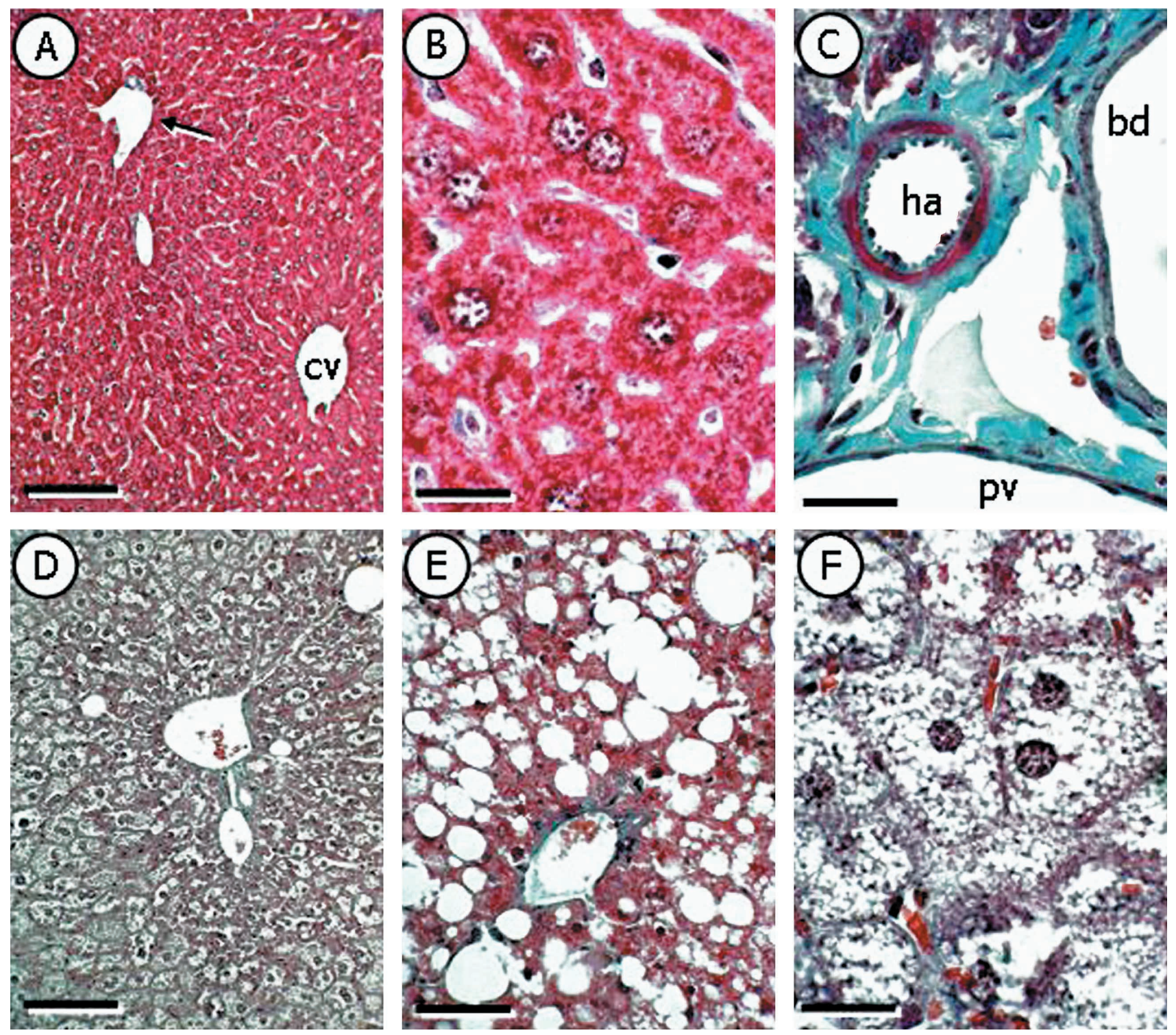

Fig. 4. Photomicrographs of the hepatic structure in animals fed standard mice chow (A, B, and C) or high fat chow (D, E, and F) (stain: H-E). A - Panoramic view of a normal mice liver shows the hepatic lobule with interlobular branches of the portal vein, bile duct and hepatic artery (portal triad, arrow). Radiating from the central vein $(\mathrm{cv})$ towards the periphery of the lobule are plates of hepatocytes and, between them, the hepatic sinusoids (bar $=300 \mu \mathrm{m})$. B - High magnification of the sinusoids (bar $=25 \mu \mathrm{m}$ ). C - High magnification of the portal triad, branches of the bile duct (bd), the hepatic artery (ha) and the portal vein (pv) $($ bar $=25 \mu \mathrm{m})$. D - Panoramic view of an abnormal mice liver. Hepatocytes are paler and bigger due to macro and macrovesicular steatosis that causes disarray of the plates of hepatocytes and consequent loss of sinusoids identify (bar $=300 \mu \mathrm{m})$. E - Hepatic lobule region with macrovesicular steatosis, altered hepatocytes and sinusoids (bar=120 $\mu \mathrm{m}$ ). F-High magnification of hepatocytes to show macrovesicular steatosis destroying cellular structure

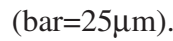




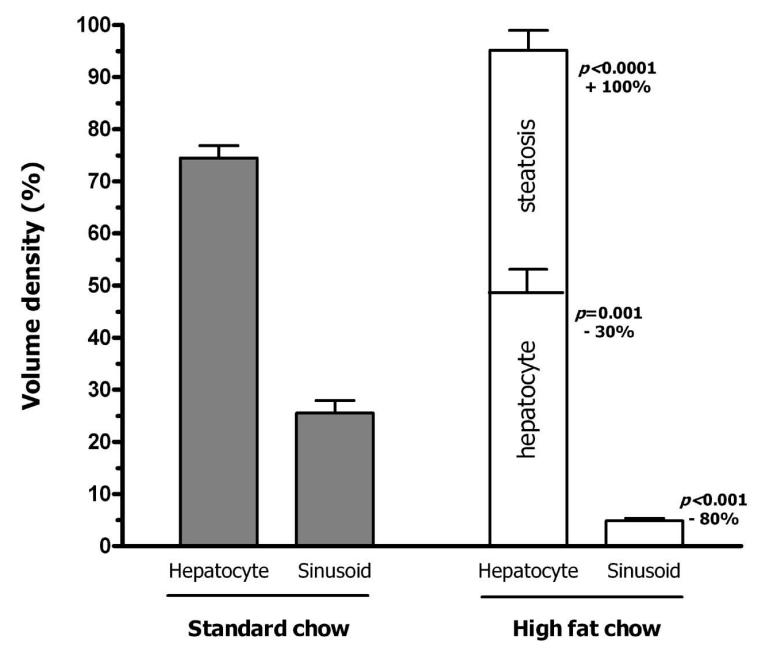

Fig. 5. Volume density of hepatic structures. Significant differences between the groups, as well as the per cent variation, are indicated over the bars.

We focused the liver structure. Animals fed SC showed liver structure without major alteration, but animals fed HFC during 30 weeks showed different degrees of fatty degeneration with micro- and macrovesicular steatosis dispersed in all liver with typical peri-cellular/peri-sinusoidal fibrosis (Fig. 4). The quantitative study showed significant volume density reduction for hepatocytes and sinusoids but steatosis appeared in animals fed HFC ( $\mathrm{Vv}$ [steatosis] is $43 \pm 10 \%$ ) (Fig. 5).

\section{DISCUSSION}

Present findings showed that dietary intervention (high fat chow) caused overweight, dyslipidemia and liver injury in mice. The precise quantification of these alterations is significant for experimental research about obesity, cardiovascular and metabolic diseases and immunity in this animal model.

The change in nutrition, in particular the consumption of energy rich diets, coming in great part from lipids, appears as a major contributor to obesity development (de Grooth $e t$ al., 2004) and obesity and weight gain are associated with future risk of coronary heart disease and type 2 diabetes (Abbasi et al., 2002; Cho et al., 2002). Obesity and hypercholesterolemia are caused by multiple environmental factors and genetic predispositions, in rodents, hypercholesterolemia occurs due to increased hepatic cholesterol synthesis and decreased LDL-c clearance, conversion of cholesterol to bile acids, and secretion of cholesterol into the bile (Mohr et al.).
In this study, the food intake was lower and body mass was greater in HFC group than in SC group perhaps due to increased metabolic efficiency of the HFC, as reported by others (Schrauwen \& Westerterp; Gaiva et al., 2001). Dietinduced obesity causes reduced energy expenditure associated with low leptin sensitivity (Widdowson et al., 1997) that could explain present results of increased body mass and circulating TC, HDL-c and LDL-c levels. The levels of TG and VLDL-c did not differ between the HFC and SC groups. The plasma lipoproteins levels observed in the present study, however, fit into the acceptable range of mice (Naveilhan et al., 2002).

The level of circulating TG is determined by a balance between delivery into the plasma and removal of TG-rich lipoproteins by tissues (i.e. muscle). Plasma TG is derived from the diet, as chylomicrons, and from hepatic synthesis and release as VLDL-c. The chylomicrons and VLDL-c undergo lipolysis in skeletal muscle and adipose tissue (Eckel, 1989). In addition, VLDL-c can be removed from the plasma by myocytes and adipocytes via the VLDL-receptor pathway (Takahashi et al., 1992). Furthermore, skeletal muscle and adipose tissue have the capacity to undergo metabolic plasticity in response to lifestyle factors (Booth, 1988). Interestingly, studies in humans have revealed that obese individuals oxidize less fat under fasting conditions and the oxidation rate does not change during an insulin infusion (Kelley et al., 1999; Kelley \& Mandarino, 2000). These data corroborate the original hypothesis that chronic consumption of the high fat diet impairs skeletal muscle TG uptake from the plasma, while increasing the TG uptake by adipose tissue, leading to obesity.

Isocaloric high-fat feeding reduces thermogenesis and increases white adipose tissue accumulation (Storlien et al., 1988). Dietetic manipulations, hormones, and cytokines induce distinct metabolic responses at different fat depots (Pond, 1999). High-fat diets reduces the activity of lipogenic enzymes and lipogenesis rate in retroperitoneal and inguinal fat depots (Rothwell et al., 1983; Gaiva et al., but increased lipoprotein lipase activity in visceral fat (Roberts et al., 2002). Also, the production of cytokines and resistin increases in obesity, which contributes to the development of insulin resistance. This production is higher in visceral fat, which is more insulin resistant than subcutaneous fat (Arner, 2003).

A major point in the present study was the quantification of the hepatic fat accumulation in the HFC animals, which caused significant macro and microvesicular disseminated steatosis. Hepatic steatosis can be distinguished as macro or microvesicular, according to the size of the lipid vacuoles. Microvesicular steatosis has been reported to be more common (Sheth et al., 1997), whereas microvesicular 
steatosis is usually described in association with more severe clinical case (Hautekeete et al., 1990; Fraser et al., 1995).

Previous study in rat demonstrated that long-term administration of lard and egg yolk attenuates hepatic fat accumulation and increases hepatic sinusoids. The administration of the canola oil and lard and egg yolk mixture increases hepatic fat accumulation, reducing the hepatic sinusoids (Aguila et al., 2003).

The present analysis used point-counting approach and stereology that is considered a technique of better reproducibility than visual evaluation and should be preferred in estimates of liver steatosis in scientific studies and in clinical contexts when the amount of steatosis is important for treatment and prognosis (Franzen et al., 2005).

Simple steatosis may progress to advanced fibrosis and to cryptogenic cirrhosis through steatohepatitis, and ultimately to hepatocellular carcinoma. Obesity is the most significant single risk factor for the development of fatty liver, both in children and in adults; obesity is also predictive of the presence of fibrosis, potentially progressing to advanced liver disease. From a pathogenic point of view, insulin resistance plays a central role in the accumulation of triglycerides within the hepatocytes and in the initiation of the inflammatory cascade (Festi et al.).

It has been speculated that a high supply in the absence of a concomitant increase in beta-oxidation could improve hepatic fat accumulation (Murase et al., 2002). However, recent evidence has indicated that dietary diacylglycerol induces alteration of lipid metabolism in the rat liver. Dietary diacylglycerol may suppress high fat diet-induced microsomal triglyceride transfer protein (MTP) activity in the liver, and indicates the possibility that hepatic triacylglycerol concentration may regulate hepatic MTP activity (Taguchi et al., 2002).

In conclusion, our results, using biochemical, histological and stereological measurements, clearly show that hepatic steatosis can be induced in mouse by such a fat-rich diet without any toxin ingestion, alimentary deficiency and genes depletion. This will allow the study of pathogenesis of diseases in a controlled and quantifiable experimental model environment.

NEVES, R. H.; ALENCAR, A. C. M. B.; AGUILA, M. B.; MANDARIM-DE-LACERDA, C. A.; MACHADO-SILVA, J. R. \& GOMES, D. C. Alteraciones somáticas, bioquímicas y hepáticas en un tipo de ratas alimentadas ccronicamente con dieta alta en grasas. Int. J. Morphol., 24(4):625-632, 2006.

RESUMEN: Este estudio evaluó cómo una dieta de alta densidad energética (grupo ADE) induce sobrepeso, esteatosis hepática y altera los niveles de las lipoproteínas plasmáticas cuando son comparados con la dieta patrón (grupo SC). Hembras de camundongos fueron sometidas a cada una de las dietas durante 6 meses. La masa corporal y la ingestión de alimento fueron evaluadas semanalmente durante el experimento. Además fueron medidos el colesterol total, TG, LDL-c, HDL-c e VLDL-c. Los animales fueron sacrificados y el hígado, bazo, corazón e intestinos fueron removidos para estudio. El volumen de los órganos fue medido por el método de la sumersión. Fragmentos de hígado fueron preparados para el estudio en microscopía de luz, teñidos con hematoxilina-eosina y tricrómico de Masson. El análisis fue realizado con video microscopía y sistema test M42. La densidad de volumen fue estimada para hepatocitos, esteatosis y sinusoides. Los animales alimentados con dieta ADE presentaron menor ingestión de alimento y tuvieron masa corporal mayor que los animales con dieta patrón. Animales ADE mostraron también hígado y bazo más pesados e intestino más liviano que animales SC $(\mathrm{p}<0.05)$. Para la masa del corazón no hubo diferencia significativa entre los dos grupos. Las lipoproteínas plasmáticas fueron diferentes entre los grupos $(\mathrm{p}<0.05)$ excepto VLDL-c y fracciones de TG. La estructura hepática no presentó grandes alteraciones en el grupo SC; sin embargo, animales del grupo ADE presentaron diferentes grados de degeneración adiposa con esteatosis macro y microvesicular dispersas en todo el hígado con típica fibrosis pericelular y perisinusoidal, y significativa reducción de la densidad de volumen de hepatocitos y sinosoides. En conclusión, los resultados muestran que la esteatosis hepática puede ser inducida experimentalmente en camundongos, a través de dieta ADE, sin ingestión de cualquier toxina, deficiencia alimentaria o depleción genética.

PALABRAS CLAVE: Hipercolesterolemia; Modelo experimental; Camundongo; Colesterol; Dieta; Hígado.

\section{REFERENCES}

Abbasi, F.; Brown, B.W., Jr.; Lamendola, C.; McLaughlin, T. \& Reaven, G. M. Relationship between obesity, insulin resistance, and coronary heart disease risk. J. Am. Coll. Cardiol., 40(5):937-43, 2002.
Aguila, M. B.; Loureiro, C. C.; Pinheiro Ada, R. \& Mandarim-De-Lacerda, C. A. Lipid metabolism in rats fed diets containing different types of lipids. Arq. Bras. Cardiol., 78(1):25-38, 2002. 
Aguila, M. B.; Pinheiro, A. R.; Parente, L. B. \& Mandarimde-Lacerda, C. A. Dietary effect of different high-fat diet on rat liver stereology. Liver Int., 23(5):363-70, 2003.

Aguila, M. B.; Sa Silva, S. P.; Pinheiro, A. R. \& Mandarimde-Lacerda, C. A. Effects of long-term intake of edible oils on hypertension and myocardial and aortic remodelling in spontaneously hypertensive rats. J. Hypertens., 22(5):921-9, 2004.

Alexaki, A.; Wilson, T. A.; Atallah, M. T.; Handelman, G. \& Nicolosi, R. J. Hamsters fed diets high in saturated fat have increased cholesterol accumulation and cytokine production in the aortic arch compared with cholesterolfed hamsters with moderately elevated plasma non-HDL cholesterol concentrations. J. Nutr., 134(2):410-5, 2004.

Arner, P. The adipocyte in insulin resistance: key molecules and the impact of the thiazolidinediones. Trends Endocrinol. Metab., 14(3):137-45, 2003.

Booth, F.W. Perspectives on molecular and cellular exercise physiology. J. Appl. Physiol., 65(4):1461-71, 1988.

Burt, A. D.; Mutton, A. \& Day, C.P. Diagnosis and interpretation of steatosis and steatohepatitis. Semin. Diagn. Pathol., 15(4):246-58, 1998.

Carson, F. L.; Martin, J. H. \& Lynn, J.A. Formalin fixation for electron microscopy: a re-evaluation. Am. J. Clin. Pathol., 59(3):365-73, 1973.

Cho, E.; Manson, J. E.; Stampfer, M. J.; Solomon, C. G.; Colditz, G. A.; Speizer, F. E.; Willett, W. C. \& Hu, F. B. A prospective study of obesity and risk of coronary heart disease among diabetic women. Diabetes Care, 25(7):1142-8, 2002

de Grooth, G. J.; Zerba, K. E.; Huang, S. P.; Tsuchihashi, Z.; Kirchgessner, T.; Belder, R.; Vishnupad, P.; Hu, B.; Klerkx, A. H.; Zwinderman, A. H.; Jukema, J. W.; Sacks, F. M.; Kastelein, J. J. \& Kuivenhoven, J.A. The cholesteryl ester transfer protein (CETP) TaqIB polymorphism in the cholesterol and recurrent events study: no interaction with the response to pravastatin therapy and no effects on cardiovascular outcome: a prospective analysis of the CETP TaqIB polymorphism on cardiovascular outcome and interaction with cholesterol-lowering therapy. J. Am. Coll. Cardiol., 43(5):854-7, 2004.

Eckel, R.H. Lipoprotein lipase. A multifunctional enzyme relevant to common metabolic diseases. N. Engl. J. Med., 320(16):1060-8, 1989.
Feingold, K.; Kim, M. S.; Shigenaga, J.; Moser, A. \& Grunfeld, C. Altered expression of nuclear hormone receptors and coactivators in mouse heart during the acute-phase response. Am. J. Physiol. Endocrinol. Metab., 286(2):E201-7, 2004.

Festi, D.; Colecchia, A.; Sacco, T.; Bondi, M.; Roda, E. \& Marchesini, G. Hepatic steatosis in obese patients: clinical aspects and prognostic significance. Obes. Rev., 5(1):2742, 2004

Franzen, L. E.; Ekstedt, M.; Kechagias, S. \& Bodin, L. Semiquantitative evaluation overestimates the degree of steatosis in liver biopsies: a comparison to stereological point counting. Mod. Pathol., 18(7):912-6, 2005.

Fraser, J. L.; Antonioli, D. A.; Chopra, S. \& Wang, H.H. Prevalence and nonspecificity of microvesicular fatty change in the liver. Mod. Pathol., 8(1):65-70, 1995.

Friedewald, W. T.; Levy, R. I. \& Fredrickson, D.S. Estimation of the concentration of low-density lipoprotein cholesterol in plasma, without use of the preparative ultracentrifuge. Clin. Chem., 18(6):499-502, 1972.

Gaiva, M.H.; Couto, R.C.; Oyama, L.M.; Couto, G.E.; Silveira, V.L.; Riberio, E.B. \& Nascimento, C.M. Polyunsaturated fatty acid-rich diets: effect on adipose tissue metabolism in rats. Br. J. Nutr., 86(3):371-7, 2001.

Glantz, S. A. Primer of biostatistics. $5^{\text {th }}$. ed. New York, McGraw-Hill, Medical Publishing Division, 2002.

Hautekeete, M. L.; Degott, C. \& Benhamou, J.P. Microvesicular steatosis of the liver. Acta Clin. Belg., 45(5):311-26, 1990.

Hu, K. Q.; Kyulo, N. L.; Esrailian, E.; Thompson, K.; Chase, R.; Hillebrand, D. J. \& Runyon, B. A. Overweight and obesity, hepatic steatosis, and progression of chronic hepatitis C: a retrospective study on a large cohort of patients in the United States. J. Hepatol., 40(1):147-54, 2004.

Kelley, D. E.; Goodpaster, B.; Wing, R. R. \& Simoneau, J.A. Skeletal muscle fatty acid metabolism in association with insulin resistance, obesity, and weight loss. Am. J. Physiol., 277(6 Pt 1):E1130-41, 1999.

Kelley, D.E. \& Mandarino, L.J. Fuel selection in human skeletal muscle in insulin resistance: a reexamination. Diabetes, 49(5):677-83, 2000.

Kim, J. K.; Gavrilova, O.; Chen, Y.; Reitman, M.L. \& 
Shulman, G.I. Mechanism of insulin resistance in A-ZIP/ F-1 fatless mice. J. Biol. Chem., 275(12):8456-60, 2000.

Lentner, C. 1981. Geigy Scientific Tables. Basle, Ciba-Geigy Limited.

Mandarim-de-Lacerda, C.A. Stereological tools in biomedical research. An. Acad. Bras. Cienc., 75(4):46986, 2003.

Marceau, P.; Biron, S.; Hould, F.S.; Marceau, S.; Simard, S.; Thung, S.N. \& Kral, J.G. Liver pathology and the metabolic syndrome $\mathrm{X}$ in severe obesity. J. Clin. Endocrinol. Metab., 84(5):1513-17, 1999.

Mohr, M.; Klempt, M.; Rathkolb, B.; de Angelis, M.H.; Wolf, E. \& Aigner, B. Hypercholesterolemia in ENU-induced mouse mutants. J. Lipid Res., 45(11):2132-7, 2004.

Murase, T.; Nagasawa, A.; Suzuki, J.; Hase, T. \& Tokimitsu, I. Beneficial effects of tea catechins on diet-induced obesity: stimulation of lipid catabolism in the liver. Int. J. Obes. Relat. Metab. Disord., 26(11):1459-64, 2002.

Naveilhan, P.; Svensson, L.; Nystrom, S.; Ekstrand, A. J. \& Ernfors, P. Attenuation of hypercholesterolemia and hyperglycemia in ob/ob mice by NPY Y2 receptor ablation. Peptides, 23(6):1087-91, 2002.

Pond, C. M. Physiological specialisation of adipose tissue. Prog. Lipid Res., 38(3):225-48, 1999.

Reue, K.; Xu, P.; Wang, X. P. \& Slavin, B. G. Adipose tissue deficiency, glucose intolerance, and increased atherosclerosis result from mutation in the mouse fatty liver dystrophy (fld) gene. J. Lipid. Res., 41(7):1067$76,2000$.

Roberts, C.K.; Barnard, R.J.; Liang, K.H. \& Vaziri, N.D. Effect of diet on adipose tissue and skeletal muscle VLDL receptor and LPL: implications for obesity and hyperlipidemia. Atherosclerosis, 161(1):133-41, 2002.

Rothwell, N.J.; Stock, M. J. \& Trayhurn, P. Reduced lipogenesis in cafeteria-fed rats exhibiting diet-induced thermogenesis. Biosci. Rep., 3(3):217-24, 1983.

Saltiel, A.R. \& Kahn, C.R. Insulin signalling and the regulation of glucose and lipid metabolism. Nature, 414(6865):799-806, 2001.

Scherle, W. A simple method for volumetry of organs in quantitative stereology. Mikroskopie, 26(1):57-60, 1970.
Schrauwen, P. \& Westerterp, K. R. The role of high-fat diets and physical activity in the regulation of body weight. Br. J. Nutr., 84(4):417-27, 2000.

Sheth, S.G.; Gordon, F.D. \& Chopra, S. Nonalcoholic steatohepatitis. Ann. Intern. Med., 126(2):137-45, 1997.

Storlien, L. H.; Kraegen, E.W.; Jenkins, A. B. \& Chisholm, D. J. Effects of sucrose vs starch diets on in vivo insulin action, thermogenesis, and obesity in rats. Am. J. Clin. Nutr., 47(3):420-7, 1988.

Taguchi, H.; Omachi, T.; Nagao, T.; Matsuo, N.; Tokimitsu, I. \& Itakura, H. Dietary diacylglycerol suppresses high fat diet-induced hepatic fat accumulation and microsomal triacylglycerol transfer protein activity in rats. J. Nutr. Biochem., 13(11):678-83, 2002.

Takahashi, S.; Kawarabayasi, Y.; Nakai, T.; Sakai, J. \& Yamamoto, T. Rabbit very low density lipoprotein receptor: a low density lipoprotein receptor-like protein with distinct ligand specificity. Proc. Natl. Acad. Sci. USA, 89(19):9252-6, 1992.

Van Steenbergen, W. \& Lanckmans, S. Liver disturbances in obesity and diabetes mellitus. Int. J. Obes. Relat. Metab. Disord., 19 Suppl 3(S27-36), 1995.

Weibel, E. R.; Kistler, G.S. \& Scherle, W.F. Practical stereological methods for morphometric cytology. J. Cell. Biol., 30(1):23-38, 1966.

Widdowson, P.S.; Upton, R.; Buckingham, R.; Arch, J. \& Williams, G. Inhibition of food response to intracerebroventricular injection of leptin is attenuated in rats with diet-induced obesity. Diabetes, 46(11):1782$5,1997$.

Correspondence to:

Dr. José R. Machado-Silva

Laboratório de Helmintologia Romero Lascasas Porto,

Disciplina de Parasitologia,

Departamento de Microbilogia, Imunologia e Parasitologia

Faculdade de Ciências M'édicas,

Universidade do Estado do Rio de Janeiro, UERJ.

Av Prof. Manoel de Abreu, 444

CEP 20551-170

Vila Isabel. Rio de Janeiro - $\mathcal{R J}$

BRAZIL .

E-mail:machado@uerj.br

Received: 10-08-2006

Accepted: 28-09-2006 